\title{
Kültürümüzde manzum yağmur duaları
}

\section{İbrahim AKYOL ${ }^{1}$}

\begin{abstract}
APA: Akyol, İ. (2020). Kültürümüzde manzum yağmur duaları. RumeliDE Dil ve Edebiyat Araştırmaları Dergisi, (18), 268-284. DOI: 10.29000/rumelide.705614.
\end{abstract}

\section{$\ddot{O} \mathbf{z}$}

Dua, kişinin Yaratıcıya taleplerini, isteklerini bildirdiği yazılı ve sözlü ifadeler olarak kabul edildiğine göre, bu talepler edebî eserlere de konu olmuşlardır. Suyun az olduğu kuraklık dönemlerinde insanların Allah'tan yağmur talebiyle topluca yaptıkları dua törenlerine yağmur duası denmekte olup bu dua törenlerinin tarihi, insanlık tarihi kadar eskidir. Halkın dini hissiyatını artırmak, toplum üzerinde etkisini daha kalıcı hale getirmek için bu duaların manzum olarak yapıldığı da görülmektedir. Çankırı ve bazı ilçelerinde yapılan yağmur duası törenlerinde okunan manzum yağmur dualarına rastlanılmıştır. Bu manzum yağmur dualarının bir kısmının aruz ölçüsü, bir kısmının ise hece ölçüsü ile yazıldı̆̆ı görülmüştür. Ayrıca bunları yazanların/ okuyanların başta Süleyman Çelebi'nin Mevlid'i olmak üzere klasik halk hikâyelerinden ve mesnevilerinden beslendikleri anlaşılmaktadır. Ayrıca bu manzumeler, Türk edebiyatındaki Divan şiiri ile Halk şiirinin aynı kaynaktan beslendiklerinin, birbiriyle içiçe olduklarının ve zaman zaman da tür ve şekillerinin birbiriyle ayırt edilmesinin de güç olduğunun bir göstergesi olarak değerlendirilebilir. Bu makalede, genel olarak yağmur duası ve ritüelleri hakkında bilgi verilmiş, Çankırı- Şabanözü yöresinde tespit edilen ve belirli bir ezgiyle okunan 5 adet manzum yağmur duası ile Çankırılı Hurrem'in yazdığ 11 adet manzum duaya yer verilmiş ve bu manzum duaların kısa bir tahlili de yapılmıştır.

Anahtar kelimeler: Divan şiiri, halk şiiri, dua, yağmur, Çankırı.

\section{The prayers for rain in verse in Turkish culture}

\begin{abstract}
As the prayer is accepted as a written or verbal statement in which a person asks for his / her demands and desires from the Creator, these demands are subject to the literary works as well. The prayer ceremonies for the rain that people demand from the God collectively during the dry periods when the water is less are called prayer for rain and the history of these prayer ceremonies is as old as the history of humanity. In these ceremonies, it is seen that prayers are performed in verse in order to increase the religious feeling of the people and to make the effect on society more permanent. The prayers for rain in verse were encountered in the rain prayer ceremonies performed in Cankiri and some of its districts. It is seen that some of these prayers for rain in verse were written in aruz prosody and the rest were written in syllabic meter. Moreover, it is understood that those who write/ read them were fed by the classic folk tales and masnawis especially the Mawlid of Suleyman Celebi. Again, these poems are an indication that Divan poetry and Folk poetry in Turkish literature are nourished from the same source, they are intertwined with each other and it is difficult to distinguish between the genres and forms of the two literatures from time to time. In this article, it is given an outline of
\end{abstract}

1 Dr. Öğr. Üyesi, Çankırı Karatekin Üniversitesi, Edebiyat Fakültesi, Türk Dili ve Edebiyatı Bölümü (Çankırı, Türkiye), iakyol18@gmail.com, ORCID ID: 00oo-0002-8363-592X [Makale kayt tarihi: 02.12.2019-kabul tarihi: 20.03.2020; DOI: $10.29000 /$ rumelide.705614] 
rain prayer and rituals, and five prayers for rain in verse which are detected in Cankiri-Sabanozu region and read with a certain tune along with one prayer in verse written by Hurrem from Cankiri are examined and analysed briefly.

Keywords: Divan poetry, folk poetry, prayer, rain, Cankiri.

\section{Giriş}

Dua, Arapça kökenli bir kelime olup lügat anlamı seslenmek, çağırmak, yardım talep etmek anlamlarındadır. "İslâm literatüründe ise Allah'ın yüceliği karşısında kulun aczini itiraf etmesini, sevgi ve tazim duyguları içinde lütuf ve yardımını dilemesini ifade eder.” (Cilacı, 1994: 529) İnsan maddî ve manevî yönleri ile yaratılmışların en mükemmeli olarak kabul edilmektedir. Bu mükemmel varlık hangi inanca ve dine mensup olursa olsun inandığı Yaratıcıya karşı değişik şekillerde halini arz eder; O’ndan istekte bulunur. O'na şükredip O’nu yüceltir. Dua, insanın ferdî olarak Yaratıcıyla kendisi arasında kurduğu, O’na aracısız doğrudan ulaşabileceği manevî bir yoldur.

İngiliz şairi ve münekkidi T.S. Eliot (1888-1965) "kültürü, herhangi bir toplumun dininin vücut bulmuş şekli” (Kaplan, 1996: 15) olarak tanımlar. Kültürü, dolayısıyla edebiyatı, dinden ve dinî değerlerden soyutlayarak incelemek mümkün değildir. Türk kültürü ve edebiyatı birçok yönden zengin ve çeşitli olduğu kadar dinî bir değer olan dua yönünden de hayli zengin ve çeşitlidir. Müslüman toplumların dua konusundaki temel referansları Kur'an-ı Kerim ve hadislerdir. Kur'an-ı Kerim'de "Bana dua edenin duasına cevap veririm” (Kur'an-ı Kerim, 2/186) "Gerçek dua, ancak O'na yapılır. O'ndan başka dua ettikleri ise, kendilerinin hiçbir isteklerini karşllayamazlar.” (Kur’an-ı Kerim, 13/14) "Duanız olmasa, Rabbim size ne diye değer versin!" (Kur'an-ı Kerim, 25/77) gibi ayetlerde ve "Dua ibadetin özüdür." (Hadislerle İslâm, 2017: 223) gibi birçok hadislerde duanın önemi ve nasıl yapılması gerektiği belirtilmiştir.

Kültür bir hayat tarzı olduğuna göre bireysel ve toplumsal hayatımızın her aşamasında dua var olagelmiştir. Bu cümleden olmak üzere: "Allah'ın adı ile başlanmayan hiçbir işte hayır yoktur." (Hadislerle İslâm, 2017: 173) hadisi bireysel ve toplumsal hayatımızın her aşamasında Allah adı ile başlamayı (besmele) ve ardından da dua etmeyi zorunlu hale getirmiştir.

"Akşam yatarken, sabah kalkarken yapılan dualar, çeşitli gülbanklar, yağmur duası, yemek duası, mevlid duası, aşure duası, nazar duası, hacı duası, mektep duası, kitap duası, bir işe başlama duası, sefer duası, çevirgel duası, battalname duası, Hızır duası, hatim duası, kayıt duası, yeni ay duası, ezan duası, hâtime duası, esnaf duası, kadeh duası, yatak duası” (Çelebioğlu, 1983: 154)

gelin alma duası, güveyi duası, ay ve güneş tutulması duaları, açılış törenlerinin duaları gibi hayatın her alanında ve aşamasında dua edilmektedir. Yani Müslüman toplumlarda yeni doğan çocuğun kulağına ezan okunmasıyla başlayan dualı hayat, ölümde ve ölümden sonra da devam etmektedir.

"İslâm kültürü içerisinde duânın tarihi gelişim sürecinde başlangıçta daha çok mensur ifâdelerle duâ edilirken sonraki devirlerde manzûm duâların rağbet gördüğü, mensûr duâlarda da secîli ifâdelerin kullanıldığı gözlemlenmektedir" (Sarıkaya, 2012:115; Uludağ, 1994: 536).

Hz. Peygamber'in dua metinlerinde iç kafiye dediğimiz secîli metinlere çokça rastlanmaktadır. Kanaatimizce bu durum İslâm toplumlarında önce secîli daha sonra manzum dualara yönelmede etkili olmuştur. 
"Ferdî ve edebî mahsullerden dua çeşidi olarak alabileceğimiz münâcât, tazarruat, niyaz-nâme, istimdâdiyye, tevbe-nâme, istiğfar-nâme, ilticâ-nâme vb. türden küçük veya büyük eserler mensur olanlarının haricinde, beyit, rubai, kıt’a, gazel, kaside, mesnevi, murabba vb. nazım şekilleriyle örnekler edebiyatımızda sayılamayacak kadar çoktur. Özellikle kasidelerin bir özelliği olarak dua ile bitmesi adeta bir zorunluluktur. Halk ve Tekke şiiri de bu yönden çok zengin olup konuyla ilgili bir kısım destanların, koşmaların, ninnilerin, manilerin v.s.nin yanında ekseriyeti münâcât ve na’t türündendir" (Çelebioğlu, 1987: 95).

Diğer yandan “Allah’tan ta'zim ile O’ndan lütuf ve yardım talebinde bulunan yani dua içerikli eserler de "duâ-nâme” veya "duâiyye" adıyla anılmaktadır" (Deniz, 2008:16). Bu duâ-nâme ve duâiyye türündeki eserlerin Klasik Türk şiirinin hemen hemen bütün nazım şekilleri ile yazıldı̆̆ı görülmektedir.

\section{Yağmur duası törenleri}

Hayatın kaynağı sudur. Suyun az olduğu kuraklık zamanlarında, yağmur yağmasını talep etmek amacıyla yapılan törenlere yağmur duası törenleri denir. Yağmur duasına İslâmî terminolojide "istiskâ" denmekte olup bunun nasıl yapılacağı da belirtilmiştir (Baktır, 2001: 381). Ancak günümüzde uygulanan yağmur duası törenlerinde eski Türk inançlarının etkisi de görülmekte olup kökeni Şamanizm’e kadar uzanan daha sonra İslâmî özelliğe bürünmüşs sözler de bulunmaktadır. ${ }^{2}$

Yağmur duası törenlerinde öncelikle o mahalde bulunan yatır/türbe gibi kutsal bilinen mekânlar ziyaret edilir. Ardından yağmur duasının yapılacağı alana gidilip orada toplu namaz kılınır. Bunlar yapılırken her bir aşamada dualar edilmekte olup bu dualar genellikle mensurdur. Ancak yapmış olduğumuz saha çalışmalarında Çankırı'nın bazı ilçelerinde ve köylerinde okunan bu duaların bir kısmının manzum karakterde olduğu tespit edilmiştir.3 Bu manzum yağmur dualarını Âmil Çelebioğlu, küçük hacimli müstakil dini şiirler grubuna dâhil eder4 (Çelebioğlu, 1983:153). Tespit edebildiğimiz ve makalemizde yer alan manzum yağmur duaları 6 adet olup bunların ilk 5’i Çankırı-Şabanözü yöresinde yağmur duası törenlerinde genellikle okunmaktadır.5 6. manzum duâ ise Çankırılı Klasik Türk şairlerinden İbrahim

2 Yağmur duası törenleri ile ilgili olarak bkz. Elif Şebnem Kobya, Türkiye’de Yağmur Törenleri ve Yağmurla İlgili İnanışlar, Atatürk Üniv., SBE, Doktora Tezi, Erzurum-2014, 487 s.; Orhan Acıpayamlı, "Türkiyede Yağmur Duası," Ankara Üniversitesi, Dil-tarih ve Coğrafya Fakültesi Dergisi, C.22, S.3-4, s.246; Bayram Polat, "Türk Kültüründe Yağmur Duası" , Dini Araştırmalar, Ocak-Nisan-2007, s.275-283; Bekir Şişman, "Samsun'da İcra Edilen Bir Yağmur Duası Ritüeli ve Türk Kültür Tarihi Bağlamında Düşündürdükleri”, Millî Folklor, C.VIII,S. 58, Yaz- 2003, s. 86-92; Metin Ekici, "Tire Yöresi Yağmur Duası Gelenekleri üzerine Bir İnceleme”, Millî Folklor, C. VII, S. 56, Kış- 2002, s. 52.

3 Eskiden beri bu dikkatle yaptığımız saha çalıșmalarında ve çocukluktan bildiğimiz kadarıyla Çankırı-Merkez, Şabanözü, Orta, Ilgaz ilçe ve köylerinde manzum yağmur duaları okunmuştur. Ancak bu manzum dualarını yazıya geçirme noktasında görüştüğümüz kaynak kişilerin hemen hemen hepsi çocukluklarında bu manzum duaları çok dinlediklerini, fakat unuttuklarını, ellerinde de yazılı olarak da bulunmadığını söylemektedirler. Bizim yayımladığımız bu manzum dualar ise, Şabanözü’nün Karakoçaş köyü ile Bakırlı köyünden derlenmiştir. Hatta kaynak kişilerimizden merhum H. Ali Ünver, Osmanlı Türkçesi ile yazdığı ilahi defterini merhum Hilmi Akyol'a vermiş, o da vefatından önce bu satırların yazarına teslim etmiştir. (Resim:1,2) Bu satırların yazarı da manzum duaları çocukluğunda çok dinlemiştir. Ayrıca tarafımızdan tespit edilen ve bu makalede yayımlanan I., III. ve IV. manzumeler, bir komisyon tarafından hazırlanmış olan “Geçmişten Günümüze Şabanözü” adlı eserde yayımlanmıştır (Şabanözü Belediyesi, Çankırı-2008, s.208-210).

4 Merhum Âmil Çelebioğlu mezkûr makalesinde manzum dini eserleri a) Küçük hacimli b) Büyük hacimli manzumeler diye ikiye ayırmıştır. Çelebioğlu'nun dikkat çektiği manzum yağmur duaları ile ilgili olarak iki çalışma tespit edilebilmiştir: 1) Orhan Acıpayaml, "Türkiye'de Yağmur Duası ve Psiko-Sosyal Metotla İncelenmesi” (Ankara Üniv. Dil ve Tarih Coğrafya Fakültesi Dergisi, C.21, S.1-2, 1963, s. 8.) başlıklı makalesinde Konya ve Uluborlu'da manzum olarak okunan toplam 30 mısra olan iki adet yağmur duası yayımlamıștır. 2) Ali Rıza Önder "Yağmur Duasından Ana Tanrıçaya" başlıklı makalesinde, (Yağmur Duası Kitabı, Editör: M. Sabri Koz, İstanbul-2007, s.259-277) Kayseri Ağırnas civarında okunan 4 ayrı manzume, toplam 64 mısradan oluşan yağmur duası yayımlamıştır. Bu manzum yağmur duası da 1 Mayıs 1325 / 14 Mayıs 1909'da Seyid Efendi-zâde Şükrü Efendi'nin kaydettiği defterden alınmıştır. Bu iki makaledeki manzum yağmur dualarından başka bir yayın tespit edilememiştir.

5 Türk sinemasında da yağmur duası törenlerine rastlanmaktadır. Başrolde Şener Şen’in oynadığı, yönetmenliğini Nesli Çölgeçen’in yaptığı, senaryosunu Yavuz Turgul'un yazdığı 1985 yapımı, Züğürt Ağa adlı filmde köyün şıhı, ağası ve halk istihza amaçlı olsa da- yağmur duasına çıkmakta, köydeki yatırlar ziyaret edilmekte ve bu esnada manzumeye benzeyen secîli dualar okunmaktadır. 
Hurrem'e (ö.1825) aittir. (Eren, 2019: 97) Hurrem’in murabba nazım şekli ile yazdığı bu dua da, Çankırı yöresinde bu manzum duaların yaygınlığı konusunda ciddi bir fikir vermektedir.

\section{3. Şekil ve muhteva özellikleri}

Metnini yayımladığımız manzum yağmur dualarından I. ve II. manzumeler mütekerrir muhammes, III. manzume ise mütekerrir müseddes, Hurrem'in manzum duası ise mütekerrir murabbâ nazım şeklinde olup ilk üçü aruzun remel bahrinin "fấilâtün fấilâtün fấilün" kahıbıyla Hurrem'in murabbâsı ise "mefầilün mefâîlün fe ûlün" kalıbıyla yazılmıştır. Kafiye şemaları ise mütekerrir muhammeslerin a a a $\mathrm{z} \mathrm{z}, \mathrm{b} \mathrm{b} \mathrm{b} \mathrm{z} \mathrm{z,} \mathrm{...,} \mathrm{mütekerrir} \mathrm{müseddesin} \mathrm{a} \mathrm{a} \mathrm{a} \mathrm{a} \mathrm{z} \mathrm{z,} \mathrm{b} \mathrm{b} \mathrm{b} \mathrm{b} \mathrm{z} \mathrm{z} \mathrm{,} \mathrm{...} \mathrm{Hurrem'in} \mathrm{murabbâsı} \mathrm{ise} \mathrm{a} \mathrm{a} \mathrm{a} \mathrm{b,} \mathrm{c} \mathrm{c} \mathrm{c}$ b, ... şeklindedir. IV. ve V. manzumeler ise koşma nazım şeklinde olup 11'li hece ölçüsüyle yazılmıştır. Kafiye şemaları ise a a a z z, b b b z z, ... şeklindedir. I. II. ve III. manzum duaların mütekerrir / nakarat beyitlerinin ilk mısraları farklı, ikinci mısraları aynı olup "ver bize bârân-ı rahmetden nasîb" şeklindedir. IV. ve V. manzum duaların da mütekerrir / nakarat beyitleri aynıdır. Mütekerrir ifadelerin tercih edilmesi, dinleyenler üzerinde manevi etkiyi arttırmaktadır. Ayrıca bu durum, manzumelerin birbirinin devamı gibi de düşünülebilir. Ancak her bir manzume farklı kaynak kişilerden tespit edildiği için çalışmamızda müstakil birer manzume olarak değerlendirilmiştir.

Muhteva olarak manzum dualarda Allah’a yalvarmadan önce günahlar itiraf edilmektedir. Nefislere zulmedildiği, onlara uyulduğu, isyankâr, âsi kullar oldukları, yüzlerinin kara olduğu, helal-haram ayırt etmedikleri, fakir ve yetimi doyurmadıkları, malın kıymetini bilmedikleri, verilen serveti çarçur ettikleri sonunda ise pişmanlık duyup tövbe ettikleri belirtilir. Bu yapılan hataların neticesinde; yer ve göğün kuraklıktan kavrulduğu, ekinlerin, bitkilerin, ağaçların kuruduğu, akarsulardan, çaylardan, çeşmelerden suların çekildiği, buğdayların, arpaların susuzluktan kavrulduğu, gökteki kuşların, leyleklerin, kargaların, atmacaların, yerdeki karıncaların rahmet umduğu, arıların, çiçeksiz, peteklerin balsız olduğu, ağaçların kuruyup yapraklarının dalsız kaldığı, fakir kulların belinin büküldüğü, böylece Allah tarafından cezalandırıldıkları pişman bir dil ile ifade edilir. Her manzum duada Allah'tan; zât-ı pâk, Hz. Muhammed (AS), kelâm, arş-1 a'zam, arş-1 a'lâ, beyt-i a'zam, ism-i a'zam, sidre ve arş-ı muallâ, sülûk-ı seyr-i a'lâ, mi‘râcda söyleşilen söz, Hakk’ı gören göz, sırr-ı Furkan, nûr-ı a'zam, kuds-i Kâbe, zemzem, Safa, Merve, Hacer-i Esved, Altınoluk, Arafat, Müzdelife Mina, ehl-i beyt, aşk ateşinden ciğeri yanan, dert ile kan ağlayan... hürmetine yağmur yağdırması talebinde bulunulur.

II. manzumede dikkat çeken bir husus da; İslâm askerine, İslâm milletine ve İslâm hâkimine (halife, sultan) duayla başlanıp ve yine Allah’tan İslâm'ın celîl, düşmanların zelîl, onları çeşitli hastalıklarla alîl eylemesi istenir. Bu manzume, Sultan II. Abdülhamid döneminin (1876-1909) genel havasını yansitmaktadır.

Metnini verdiğimiz manzum yağmur dualarındaki III. manzumenin 1. bendindeki: "Yâ İlâhî ol Muhammed hakkıçün /Ol şefaat kânı Ahmed hakkıçün” beyti halk tipi Mevlidü’n-Nebî’de, (Arvas, 2017: 229) aynı manzumenin 4. bendindeki: "Cümlemiz isyânımızı bilmişiz / Huzura rahmet ummaya gelmişiz" beyitleri ise Süleyman Çelebî’nin "Mevlid”inde geçmektedir (Pekolcay, 2005: 166). Ancak bizim derlediğimiz bu manzumelerin yazarları bilinmemesine rağmen zamanla bu manzumelere eklemeler ve çıkarmalar yapıldığı da anlaşılmaktadır. Öte yandan bu manzumelerin vezni, başta Mevlidi Nebi, Hikâye-i Kesikbaş, Hikâye-i Deve, Hz. Ali, Muhammed Hanefi cenkleri gibi manzum halk hikâyelerinin vezinleri ile aynıdır. Derlediğimiz kaynak kişilerden H.A. Ünver, H. Akyol ve F. Haliloğlu'nun ise yukarıda adı geçen halk hikâyelerinin yanında Anadolu'da çokça okunan Bîcân kardeşlerin manzum olarak yazdığı Muhammediye, Ahmediye gibi dini-tasavvufî eserleri de okudukları 
bilinmektedir. Böylece manzum yağmur dualarını yazanların/okuyanların hangi kaynaklardan beslendikleri de genel olarak ortaya çlkmaktadır.

Ayrıca yer yer hâlâ devam eden bu geleneksel okumalarda her bahrin/manzumenin sonunda söylenen "Fâ‘ilâtün fấilâtün fâ‘ilât / Ver Muhammed Mustafaya es-salât" mütekerrir beytin okunması -bilinçli bir tavır olmamasına rağmen- aruzun bu kalıbını bir form haline getirmiş̧ir. Bir başka ifadeyle bu tarz manzumelerin sonunda okunan bu beyit, mevlid türünün her bahrinin sonundaki mütekerrir vasita beyitleri ${ }^{6}$ ile terkib ve terci'-bendlerdeki vasıta beyitlerinin fonksiyonunu yerine getirmektedir. Diğer yandan bu manzum yağmur dualarında aruz ölçüsü ile hece ölçüsü iç içedir.

Fuat Köprülü, "Halk edebiyatı ile Klasik edebiyatın birbirleri üzerinde bir takım tesirleri” olduğuna dikkat çekerken (Köprülü, 1980:117-118) Mehmet Çavuşoğlu,

“18. ve 19. yüzyllardan günümüze kalan cönklerde okuma-yazma bilen halk kesiminden kişilerin derledikleri defterlerde, özellikle 16. yüzyılda Bâkî, Fuzûlî, Yahya Bey, Hayretî gibi ünlü şairlerin şiirlerine rastlanıldığını, dolayısıyla Divan şiirinin sadece yüksek aydın kesiminde okunmakla kalmadığı" (Çavuşoğlu, 1986: 8)

tespitinde bulunmaktadır. Âmil Çelebioğlu;

"Halk ve Divan edebiyatımızı bütünüyle birbirine aykırı veya farklı göstermenin onları ayrı bir kültürün, zevkin mahsulleri imiş gibi kabul etmenin ve devamlı olarak bu şekilde ele almanın doğru olmadığını, Halk şiiri ile Divan şiiri arasında gerek dil ve şekil, gerek muhteva bakımından farklılıklar bulunmakla beraber neticede aynı milletin malı olarak bunların temelinde zevk, duygu, heyecan ve fikirde birlik ve benzerliğin mevcudiyetinin tabîi ve zaruri” (Çelebioğlu, 1998: 711)

olduğuna dikkat çekmektedir. Cemal Kurnaz ise;

"Halk şairlerinin Divan şairlerinden etkilenmesinin kültür gelişiminin tabii bir neticesi olduğunu, bu etkileşimin son asırlara doğru daha çok hissedildiğini, bu temayül ve etkileşimin halkın sanat, kültür zevki ve seviyesinin artmasiyla ilgili” olduğunu belirtir (Kurnaz, 1990: 59).

Yukarıda tespit edilen durumlar, Divan şiiri ile Halk şiirinin aynı kaynaktan beslendiğini, birbiriyle iç içe olduklarının bir göstergesi ve cemiyet (kesret) içinde vahdetin bir yansıması olarak yapılan değerlendirilmeleri güçlendirmektedir. Ayrıca bu manzumeler, Divan şiiri ile Halk şïirinin birbiriyle iç içe olduğunun ve iki edebiyat ürününün birbirinden ayırt edilemeyecek durumda olduğunun bir ispatı olarak da okunmalıdır.

\section{Sonuç}

Dua, Yüce Yaratıcıdan kişilerin ferdî veya topluca taleplerini, isteklerini bildirdikleri yazılı ve sözlü ifadeler olduğuna göre bu talepler edebiyata da konu olmuştur. Suyun az olduğu kuraklık dönemlerinde insanların Allah'tan yağmur talebiyle topluca yaptıkları dua törenlerine yağmur duası denmekte olup bu dua törenlerinin tarihi, insanlık tarihi kadar eskidir. Bu törenlerdeki duaların daha etkili ve daha kalıcı olmasını sağlamak için zaman zaman manzum olarak yapıldığı görülmektedir.

Bu çerçeveden olmak üzere Çankırı ve yöresinde yağmur duası törenlerinde okunan manzum yağmur dualarına rastlanmaktadır. Bu yağmur dualarının genel olarak yazarlarının bilinmemesi, bazı Divan şairlerinin de manzum yağmur duası yazmaları dikkat çekici bir durumdur.Metni verilen manzum

$6 \quad$ Başta Süleyman Çelebi olmak üzere bütün mevlid yazarları her bahrin sonunda bir vasıta beyti koymuşlardır. Süleyman Çelebi'nin Vesiletü’n-Necât'ındaki vasıta beyti ise “Ger dilersiz bulasız oddan necât / Aşk ile derd ile edin es-salât"tır. (Pekolcay, 2005:54) 
yağmur duaları Çankırı yöresinde tespit edilmiştir. Bu manzumelerin yanı sıra bu tarz başka manzumelerin var olduğu ancak zamanla kaybolduğu tespit edilmiştir. Ayrıca bu manzumeler, yağmur duası törenlerinde türbe ve yatırlar ziyaret edilirken belirli kişiler tarafından genellikle aruzun ahengine uygun olarak ezgi ile okunmaktadır.

Bu manzum yağmur dualarını yazanların / okuyucuların klasik halk hikâyelerinden ve mesnevilerden beslendiği anlaşlmakta olup bu manzumelerin bir kısmı aruz veznine bir kısmı da hece ölçüsüne uymaktadır. Bu tespitler, Divan şiiri ile Halk şiirinin aynı kaynaktan beslendiği, birbiriyle iç içe oldukları görüşünü güçlendirmektedir. Diğer yandan bu anonim manzumelerden 3’ünün aruzun remel bahrindeki -aynı zamanda tuyuğun da kalıbı olan- "fâ‘ilâtün fâ‘ilâtün fâ‘ilün" kalıbıyla yazılması, Türk aruzu tartışmalarında yadsınamayacak bir durumdur.

\section{Manzum yağmur duaları}

I

(Fấilâtün fấilâtün fấilün)

Rabbenâ sensin kamûlardan Kerîm

Kapına geldik bizi kılma elîm

Beldemizi kıl kazâlardan emîn

Zât-ı pâkin hürmetine yâ Mücîb

Ver bize bârân-1 rahmetten nasîb

Tıfl-ı ma‘sûmlar geliyor kapına

Cümlenin niyâzı vardır katına

Kıl bize lâyık olanı şânına

Ol Muhammed hürmetine yâ Mücîb

Ver bize bârân-ı rahmetten nasîb

Bu gedâ kullara yâ Rab eyle dâd

Rızkımızı eyle fazlınla ziyâd

Cümlenin maksûdunu kıl eyle şâd

Arş-ı a'zam hürmetine yâ Mücîb

Ver bize bârân-ı rahmetten nasîb

Rabbenâ cürm ü hatâlar kılmışız

Tövbeler olsun nedâmet bilmişiz

Rahmet ummaya kapına gelmişiz

Ol kelâmın hürmetine yâ Mücib

Ver bize bârân-ı rahmetten nasîb

Sana yalvarıp İlâhe'l-âlemîn

Derdimize kıl devâsın ey tabîb

Ol Muhammed hürmetine ey Kerîm 
Ol kelâmın hürmetine yâ Mücîb

Ver bize bârân-ı rahmetten nasîb

Kapına geldik İlâhe’l-âlemîn

Her kazâlardan bizi eyle emîn

İsm-i a'zam hürmetine yâ Muîn

Ol kelâmın hürmetine yâ Mücîb

Ver bize bârân-ı rahmetten nasîb

On sekizbin âleme sensin Hudâ

Var recâmız hazretinden kıl edâ

Sevgili Habîb Muhammed Mustafâ

Ol Muhammed hürmetine yâ Mücîb

Ver bize bârân-ı rahmetten nasîb

Tıfl-ı ma'sûmâne eyle şefkati

Bî-cürüm hayvâna yağdır rahmeti

Ver Muhammed ümmetine ni'meti

Beyt-i a'zâm hürmetine yâ Mücîb

Ver bize bârân-ı rahmetten nasîb

II

(Fâilâtün fấilâtün fấilün)

Asker-i İslâm'a yâ Rab eyle dâd

Millet-i İslâm'ı yâ Rab eyle şâd

Hâkim-i İslâm'ı yâ Rab eyle dâd

Ol Muhammed hürmetine yâ Mücîb

Ver bize bârân-ı rahmetten nasîb

Dîn-i İslâmı yâ Rab kıl celîl•

Dîn-i a'dâyı yâ Rab kıl zelîl

Muhtelif emrâz ile eyle alîl

Ol Habîbin hürmetine yâ Mücîb

Ver bize bârân-1 rahmetten nasîb

Binbir ismin hürmetine Rabbenâ

Cümle Peygamber hürmetine Rabbenâ

Hûr-i cennet hürmetine Rabbenâ

Zât-ı pâkin hürmetine yâ Mücîb

\footnotetext{
- Vezin aksamaktadır
} 
Ver bize bârân-ı rahmetten nasîb

Yâ İlâhî kıl duâmız müstecâb

Bakma sen noksânımıza feth-i bâb

Rızkımızı ver hayır ile sevâb

İsm-i a‘zâm hürmetine yâ Mücîb

Ver bize bârân-1 rahmetten nasîb

Rabbenâ sensin kullara dest-gîr

Cümlenin ahvâline sensin habîr

Rahmetin muhtâcıdır cümle gedâ

Arş-1 a'lâ hürmetine yâ Mücîb

Ver bize bârân-ı rahmetten nasîb

Ol Habîbin ehl-i beyti hürmeti

Verme erzâkda ibâda kılleti

Mezru'âta yağdır ol sen rahmeti

Ol Muhammed hürmetine yâ Mücîb

Ver bize bârân-ı rahmetten nasîb

Rabbenâ sensin Hüdâ ferdü's-Samed

Zât-1 pâkin "lem yelid ve lem yuled"7

Eyle hayvânata yâ Rab rahmeti

Ol Habîbin hürmetine yâ Mücîb

Ver bize bârân-ı rahmetten nasîb

Bunda kullarına yâ Rab eyle dâd

Rızkımızı eyle fazlınla ziyâd

Cümlenin maksûdunu sen eyle şâd

Zât-ı pâkin hürmetine yâ Mücîb

Ver bize bârân-ı rahmetten nasîb

On sekiz bin âleme sensin Hudâ

Var recâmız Hazretinden kıl edâ

Rahmetin muhtâcıdır bây u gedâ

İsm-i a'zâm hürmetine yâ Mücîb

Ver bize bârân-ı rahmetten nasîb

“O doğurmamış ve doğmamıştır.” Kur’an-ı Kerim, 112/3. 
Cümle âlem halkının Hallâkı sen

Cümle rızkı yiyenin Rezzâkı sen

Cümle ed'afı mudâaf eyle sen

Ol Muhammed hürmetine yâ Mücîb

Ver bize bârân-ı rahmetten nasîb

\section{III}

(Fâ'ilâtün fấilâtün fấilün)

Yâ İlâhî ol Muhammed hakkıçün

Ol şefâat kânı Ahmed hakkıçün

Sidre vü arş-ı muallâ hakkıçün

Ol sulûk-i seyr-i a'lâ hakkıçün

Ol kelâmın hürmetine yâ Mücîb

Ver bize bârân-ı rahmetten nasîb

Önce söyleşilen ol söz hakkıçün

Ol gece Hakk’ı gören göz hakkıçün

Sırr-ı Furkan Nur-ı a'zâm hakkıçün

Kuds-i Ka‘be Merve Zemzem hakkıçün

Ol Muhammed hürmetine yâ Mücîb

Ver bize bârân-ı rahmetten nasîb

Aşk odundan ciğeri biryân içün

Dert ile kan ağlayan giryan içün

Afv edip isyânımız kıl rahmeti

Ol Habîbin yüzü suyu hürmeti

Ol kelâmın hürmetine yâ Mücîb

Ver bize bârân-ı rahmetten nasîb

Cümlemiz isyânımızı bilmişiz

Huzura rahmet ummaya gelmişiz ${ }^{\bullet}$

Umarız senden inâyetler ola

Rahmet erişe şefâatler ola

Ol Muhammed hürmetine yâ Mücîb

Ver bize bârân-ı rahmetten nasîb

\section{IV}

(11'li hece ölçüsüyle yazılmıştır.)

Allah birdir deyip düştük yollara

- Vezin aksamaktadır. 
Sana varmak için yüzümüz kara

Başka bir Rab yok ki gidelim nere

Semâdan indir bize rahmetini

Kuru yerlerde bitir nimetini

Ekinler kurudu yere döküldü

Fukara kulların beli büküldü

Çeşmeler kurudu sular çekildi

Semâdan indir bize rahmetini

Kuru yerlerde bitir nimetini

Gökte kuşlar yerde bütün karınca

Sevinirler bundan rahmet bulunca

Rahmet saçıp suyu yerli yerince

Semâdan indir bize rahmetini

Kuru yerlerde bitir nimetini

Gökte kuşlar leylek, karga, atmaca

Yerde mahlûk karıncaya varınca

Sevinir cümlesi yağmur yağınca

Semâdan indir bize rahmetini

Kuru yerlerde bitir nimetini

Günahımız bilip tövbe eyledik

Nefsimize uyup bilmem n'eyledik

Ümidimiz Sensin Sana yöneldik

Semâdan indir bize rahmetini

Kuru yerlerde bitir nimetini

Cibrîl ile bize indirdin Kur’an

Okun, dinlen, uyun buyurdun her an

Buyruğun tutmadık halimiz yaman

Semâdan indir bize rahmetini

Kuru yerlerde bitir nimetini

Anam babam cânım yoluna fedâ

Yolumuz aydınlat olmayak gedâ

Rahmansın Rahimsin bir ismin Hüdâ

Semâdan indir bize rahmetini

Kuru yerlerde bitir nimetini 
Ol Resûlü Kibriyâ'nın hürmeti

Kâbe Zemzem Safa Merve hürmeti

Hacer Esved Altınoluk hürmeti

Arafat Müzdelife Minâ hürmeti

Semâdan indir bize rahmetini

Kuru yerlerde bitir nimetini

V

(11'li hece ölçüsüyle yazılmıştır.)

Rahmetini umarak geldik sana

İsyankâr kullarız yüzümüz kara

Lakin düştük biliyorsun çok dara

Semâdan indir bize rahmetini

Kuru yerlerde bitir nimetini

Helal haram cümlesini bir tuttuk

Zulmederek nefsimizi uyuttuk

Bugün akıl başa geldi çok korktuk

Semâdan indir bize rahmetini

Kuru yerlerde bitir nimetini

Şimdi yorgun düşmüş gönüller pişman

Nefsimize olduk kendimiz düşman

Sana döndük kalbimiz diler aman

Semâdan indir bize rahmetini

Kuru yerlerde bitir nimetini

Var iken bilmedik mal kıymetini

Doyurmadık öksüz fakir yetimi

Çarçur ettik verdiğin servetini

Semâdan indir bize rahmetini

Kuru yerlerde bitir nimetini

Kitlık geldi dayandı kapımıza

Bereket ver ekmek ve aşımıza

Kara kilit vurmadan evimize

Semâdan indir bize rahmetini

Kuru yerlerde bitir nimetini 
Akarsular durdu çaylar kurudu

Buğdaylar arpalar yandı kavruldu

Boşa gitti emekler hep savruldu

Semâdan indir bize rahmetini

Kuru yerlerde bitir nimetini

Arılar çiçeksiz petekler balsız

Kurudu ağaçlar yapraksız dalsız

Çâre yâ Rab kaldı mahlûkat halsiz

Semâdan indir bize rahmetini

Kuru yerlerde bitir nimetini

Susuzluktan kalmadı mecâlimiz

Acınacak durumdayız hepimiz

Vermez isen ne olacak hâlimiz

Semâdan indir bize rahmetini

Kuru yerlerde bitir nimetini

Şarktan garba muhtacız sana yâ Râb

Rahmetini vermezsen haller harap

Göl üstünde dursak oluyor serap

Semâdan indir bize rahmetini

Kuru yerlerde bitir nimetini

Ol der isen tüm âlem oluverir

Dol der isen tüm âlem doluverir

Sen vermezsen yâ Rab bize kim verir

Semâdan indir bize rahmetini

Kuru yerlerde bitir nimetini

Sonsuz rahmet kapıların aç bize

Sen merhamet damlaların saç bize

Türlü türlü nimetini biç bize

Semâdan indir bize rahmetini

Kuru yerlerde bitir nimetini

Gayrı kurtar çektirme bize çile

İsyan değil getirdiğimiz dile

Gelsin huzur bolluk bereket ile

Semâdan indir bize rahmetini 
Kuru yerlerde bitir nimetini

Yâ İlâhî sana sığınıyoruz

Şu azgın nefsimizi kınıyoruz

Susuzluk kapıda kıvranıyoruz

Semâdan indir bize rahmetini

Kuru yerlerde bitir nimetini

Damla damla yağmurundan ver bize

Halı gibi yeşillikler ser bize

Güç kuvvet ver dayanacak fer bize

Semâdan indir bize rahmetini

Kuru yerlerde bitir nimetini

Onsekizbin âlemin Peygamberi

Enbiyâlar asfiyalar serveri

Hürmetine ol Muhammed son Nebi

Semâdan indir bize rahmetini

Kuru yerlerde bitir nimetini

\section{VI}

\section{Çankırılı Hurrem’in manzum yağmur duası}

(Mefâî̀iün mefâîilün fe ûlün)

Hudâvendâ sana hamd ola her ân

Resûlüne salât olsun firâvân

Meded kat'-1 matardan cümle nâlân

Nüzûl-i rahmetinle eyle şâdân

İlâhî âb-ı feyzin eyle cârî

Cihân bulsun safâ-yı nev-bahârı

Vuhûş u tayr eder feryâd u zârı

Nüzûl-i rahmetinle eyle şâdân

Senindir cümle mahlûk ins ile cân

Olurlar rûz u şeb sûzân u giryân

Kerem kıl eylegil ihsân-ı bârân

Nüzûl-i rahmetinle eyle şâdân 


\begin{abstract}
Budur va'din Muhammed Mustafâ'dan
Ümîdi kesmeyüz dest-i recâdan

Bizi redd eyleme bâb-ı 'atâdan

Nüzûl-i rahmetinle eyle şâdân

Gülistân-ı cihân olsun mutarrâ

Açılsun goncalar bülbül de gûyâ

Ola her bir varak [ol] verd-i ra'nâ

Nüzûl-i rahmetinle eyle şâdân

Kurudu yeryüzü kaht oldu 'âlem

Eder cümle halayık zâr u mâtem

Kerîmâ Girdigâra sensin erham

Nüzûl-i rahmetinle eyle şâdân (Eren, 2019: 97)
\end{abstract}

\title{
Kaynak kişiler
}

Haliloğlu, F. (d.1934), İlkokul mezunu, emekli din görevlisi.

Ünver, H. A. (1322/1907-1997), İlkokul mezunu, çiftçi.

Ünver, A. (d. 1961), Lise mezunu, emekli din görevlisi.

Akyol, H. (1927-2012), İlkokul mezunu, çiftçi.

Uzunosmanoğlu, İ. (d.1967), Ortaokul mezunu, esnaf.

\section{Kaynakça}

Acıpayamlı, O. (1963), "Türkiye'de Yağmur Duası ve Psiko-Sosyal Metotla İncelenmesi," Ankara Üniversitesi, Dil-Tarih ve Coğrafya Fakültesi Dergisi, C.22, S.3-4.

Baktır, M. (2001), "İstiskâ" mad. TDVİA, C.23, İstanbul.

Cilacı, O. (1994), “Dua” mad. TDVİA, C.9, İstanbul.

Çavuşoğlu, M. (1986), Divan Şiiri, Türk Dili, Türk Şiiri Özel Sayısı II, S.415, 416, 417, Ankara.

Çelebioğlu, Â. (1983), “Türk Edebiyatında Manzum Dini Eserler”, Şükrü Elçin Armağanı, Ankara.

Çelebioğlu, Â. (1987). “Kültürümüzde Yatak Duaları” III. Milletlerarası Türk Folklor Kongresi Bildirileri, C.IV, Ankara.

Çelebioğlu, Â. (1998), “Karacaoğlan'da Divan Şiiri Hususiyetleri” Eski Türk Edebiyatı Araştırmaları, İstanbul: MEB.

Deniz, S. (2008), “Kadızâde Mehmed İlmî’nin Sultan IV. Murad İçin Yazdığı Manzum Duânâme’si”, Divan Edebiyatı Araştırmaları Dergisi 1, İstanbul.

Ekici, M. (2002), “Tire Yöresi Yağmur Duası Gelenekleri üzerine Bir İnceleme”, Millî Folklor, C. VII, S. 56 , Kış.

Komisyon, (2017), Hadislerle İslam, İstanbul:DİB Yayınları.

Aslan,Y., Akyol, İ., Metin E., Türkoğlu, Ö., Softa, S., Alper, K., (2008) Geçmişten Günümüze Şabanözü, Çankırı: Şabanözü Belediyesi Yayınları.

Eren, A. (2019), Hânî-zâde Seyyid İbrahim Hurrem Dîvânı, Ankara: Gece Akademi.

Kaplan, M. (1996), Kültür ve Dil, İstanbul: Dergâh. 
Kobya, E. Ş. (2014), Türkiye'de Yağmur Törenleri ve Yağmurla İlgili İnanışlar, Atatürk Üniv., SBE, Doktora Tezi, Erzurum.

Köprülü, M. F. (1980), Türk Edebiyatı Tarihi, İstanbul: Akçă̆.

Arvas, A. (2017), Bir Halk Kitabı Olarak Mevlidü’n-Nebî, Ankara: Sonçağ.

Pekolcay, N. (2005), Mevlid-Süleyman Çelebi, İstanbul: Sufi.

Kurnaz, C. (1990), Halk ve Divan Şiirinin Müşterekleri Üzerine Denemeler, Ankara: Akçă̆.

Önder, A. R. (2007) "Yağmur Duasından Ana Tanrıçaya," Yağmur Duası Kitabı, Editör: M. Sabri Koz, İstanbul: Kitabevi.

Polat, B. (2007) “Türk Kültüründe Yağmur Duası”, Dini Araştırmalar, Ocak-Nisan.

Sarıkaya, M. Y. (2012) “ Halk Dilinde Bir Duâ Mecmûası” İstanbul Üniversitesi İlahiyat Fakültesi Dergisi, 27.

Şişman, B. (2003) “Samsun'da İcra Edilen Bir Yağmur Duası Ritüeli ve Türk Kültür Tarihi Bağlamında Düşündürdükleri”, Millî Folklor, C.VIII,S. 58, Yaz.

Uludă̆, S. (1994) “Tasavvufta Dua Anlayışı “ TDVİA, C. 9, İstanbul. 


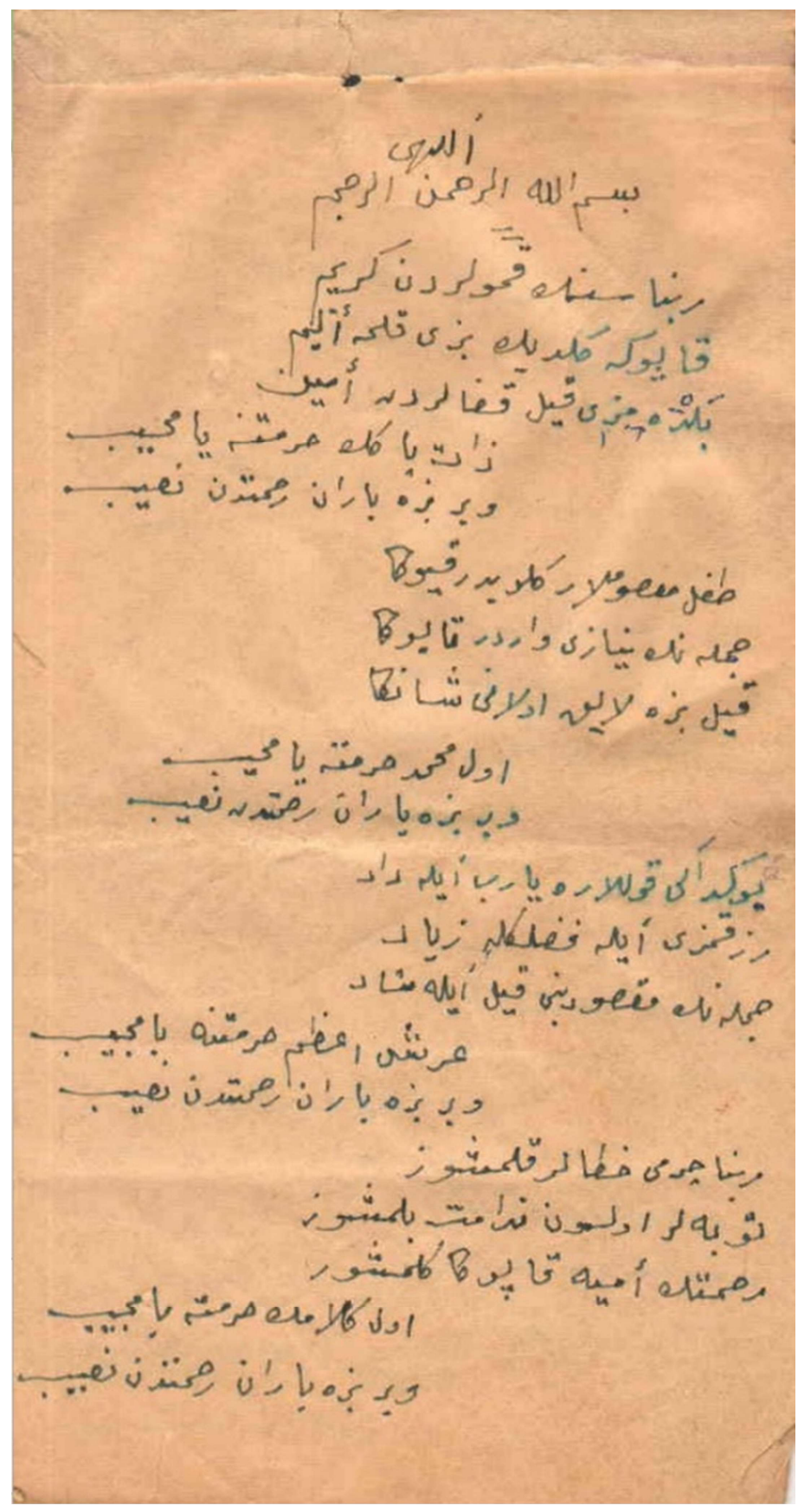

$(\operatorname{Resim} 1)$ 


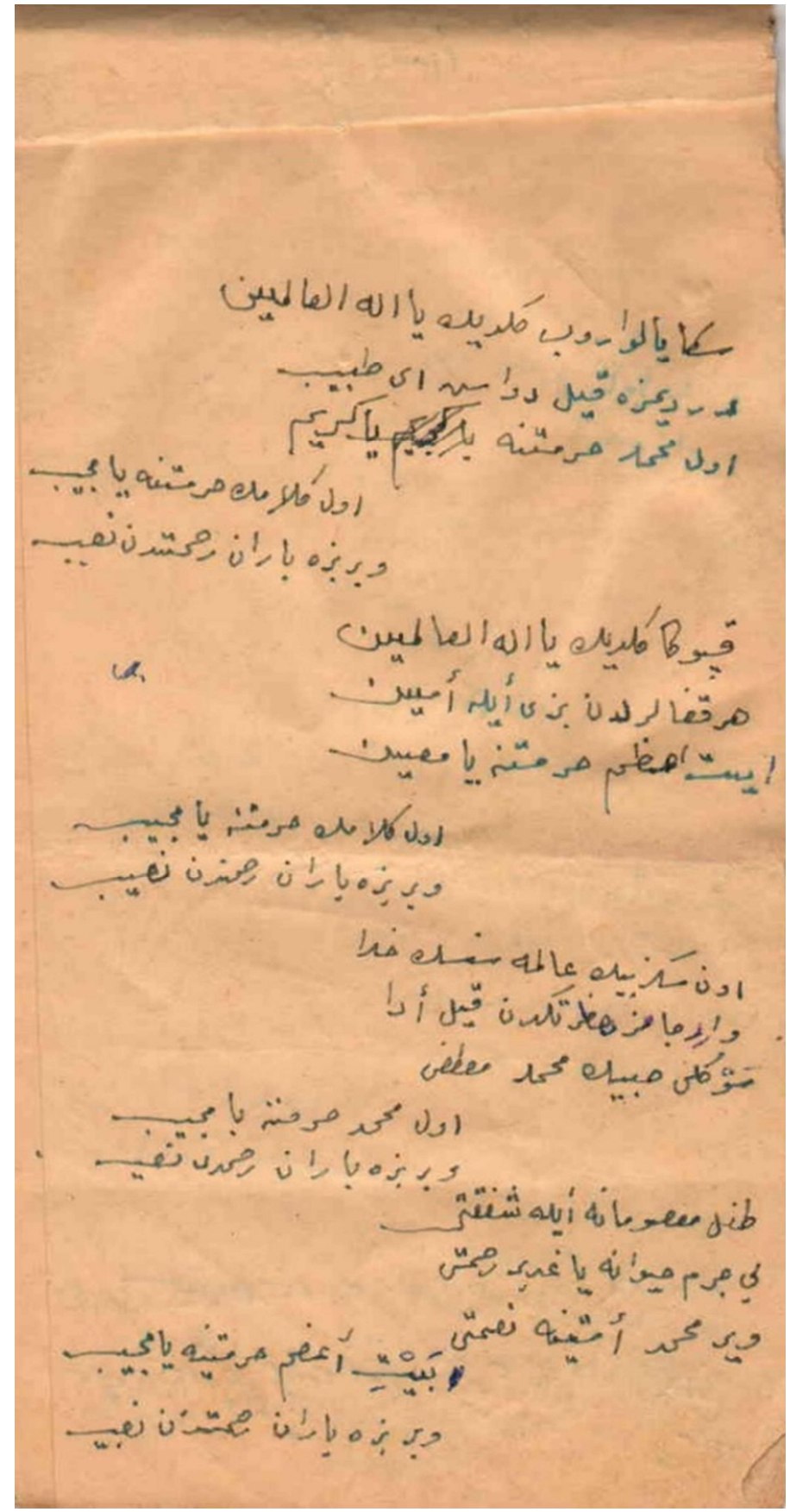

(Resim 2) 